\author{
JURNAL Midwifery Update (MU) \\ http://jurnalmu.poltekkes-mataram.ac.id/index.php/jurnalmu \\ e-ISSN:2684-8511 (Online)
}

\title{
PENGARUH MASASE ENDORPHIN TERHADAP PENINGKATAN PRODUKSI ASI PADA IBU POST PARTUM DI WILAYAH KERJA PUSKESMAS BAGU
}

\author{
Baiq Mei Asri Pratimi ${ }^{1}$, Ernawati ${ }^{2}$, Baiq Eka Putri Saudia ${ }^{3}$ \\ ${ }^{1}$ Sekolah Tinggi Ilmu Kesehatan Hamzar, Lombok Timur-NTB \\ ${ }^{2}$ Sekolah Tinggi Ilmu Kesehatan Hamzar, Lombok Timur-NTB \\ ${ }^{3}$ Poltekkes Kemenkes Mataram
}

\begin{abstract}
ABSTRAK
Studi pendahuluan yang dilakukan di Puskesmas Bagu, dari delapan ibu yang melahirkan, empat diantaranya (50\%) pengeluaran ASI belum lancar/belum keluar sama sekali pada hari pertama persalinan. Salah satu teknik untuk meningkatkan produksi ASI adalah dengan pemberian masase endorphin yaitu salah satu teknik sentuhan dan pemijatan ringan yang dilakukan untuk memberikan rasa nyaman, rileks dan merangsang refleks oksitosin atau let down reflex. Penelitian ini bertujuan untuk mengetahui efek masase endorphin terhadap peningkatan produksi ASI pada ibu post partum. Jenis penelitian ini adalah quasi experiment dengan desain penelitian non equivalen control group design. Penentuan sampel menggunakan metode accidental sampling. Besar sampel $30 \mathrm{ibu}$ post partum yang memenuhi kriteria inklusi, masingmasing 15 sampel untuk kelompok perlakuan dan kelompok kontrol. Data yang terkumpul dianalisa menggunakan Wilcoxon Signed Ranks Test. Hasil penelitian menunjukkan bahwa produksi ASI sebelum masase endorphin pada kelompok kontrol dengan rerata 2.667 dan pada kelompok perlakuan dengan rerata 2.400, peningkatan produksi ASI pada setelah masase pada kelompok kontrol adalah 3.267 dengan $p=$ 0.259 dan pada kelompok perlakuan dengan rerata 4.933 dengan $p=0.001(p<0.05)$. Disimpulkan bahwa masase endorphin memiliki pengaruh yang signifikan terhadap peningkatan produksi ASI pada ibu post partum.
\end{abstract}

Kata kunci: Masase endorphin, produksi ASI, post partum.

\section{ABSTRACT}

Preliminary studi in Bagu Health Center showed that 4 of 8 women (50\%) breast milk come out smoothly and the rest did not come out at all. One of techniques to improve better production of breast milk is through providing endorphin massage by making soft touch to provide convenience, relaxtion, and stimulating oxytocin reflex or let down reflex. This research is aimed at determining the effect of endorphin massage on the improvement of breast milk production of postpartum women in the working area of Bagu Health center. This research is quasi experiment using non-equivalent control group design. The samples were sellected through accidental sampling to get 30 women of postpartum that fulfil the inclusive criteria. 15 samples were of each of control and treatment group. The data were collected were analyzed with Wilcoxon Signned Ranks Test. The research showed that breast milk production before the endorphin massage treatment of control group is 2.667 in average and that of treatment group is 2.440 in average. The improvement of breast milk production after endorphin massage of control group is 3.267 in average with $p=0.259$ and that of treatment group is 4.933 in average with $p=0.001(p<0.05)$. it is inferred that 
endorphin massage had significant effect on the improvement of breast milk production pf postpartum womens. It is suggested that Bagu Health center apply endorphin massage for postpartum womens.

Keywords: endorphin massage, breast milk production, postpartum.

\section{PENDAHULUAN}

Masa post partum merupakan periode penting dalam hidup seorang ibu dimana pada masa ini seorang ibu mengalami berbagai macam perasaan, antara lain bahagia karena berhasil mempunyai anak, namun ada kalanya muncul perasaan bingung dengan tanggung jawabnya yang baru sehingga seorang ibu mengalami kelelahan yang dapat mengakibatkan penurunan produksi Air Susu Ibu (ASI) ${ }^{22}$.

ASI memberikan seluruh kebutuhan nutrisi dan energi selama enam bulan pertama, separuh atau lebih nutrisi selama 6 bulan kedua dalam tahun pertama, dan 1/3 nutrisi atau lebih selama tahun kedua, zat gizi yang terdapat dalam ASI antara lain lemak, karbohidrat, protein, garam dan mineral serta vitamin ${ }^{2}$.

Laktasi adalah keseluruhan proses menyusui mulai dari ASI di produksi, disekresi, dan pengeluaran ASI sampai pada proses bayi menghisap dan menelan ASI, dimana menyusui merupakan suatu proses alamiah, namun sering ibu-ibu tidak berhasil menyusui atau menghentikan menyusui lebih dini. Oleh karena itu ibu memerlukan bantuan agar proses menyusui lebih berhasil. Banyak alasan yang dikemukakan oleh ibu-ibu yang tidak menyusui bayinya antara lain ibu tidak memproduksi cukup ASI, padahal sesungguhnya hal itu disebabkan karena ibu kurang percaya diri bahwa ASI-nya cukup untuk bayinya ${ }^{12}$.

Menurut data SDKI tahun 2012, jumlah ibu menyusui adalah sekitar 42\% namun hanya $44 \%$ yang berhasil laktasi pada 1 jam pertama setelah lahir dan hanya $62 \%$ dalam hari pertama setelah lahir serta 50,8\% dalam 1 bulan pertama kelahiran. Pemberian ASI awal dapat mempengaruhi pemberian ASI pada bayi sampai usia 6 bulan (ASI Eksklusif). Menurut data WHO (2016), cakupan ASI eksklusif di seluruh dunia hanya sekitar 36\% selama periode 2007-2014.

Tidak semua ibu post partum langsung mengeluarkan ASI, karena pengeluaran ASI merupakan interaksi yang sangat kompleks antara rangsangan mekanik, saraf dan bermacam macam hormon yang berpengaruh terhadap pengeluaran oksitosin ${ }^{28}$.

Berdasarkan penelitian yang dilakukan Hastuti dan Wijayanti (2017) tentang ASI tidak lancar dari 30 responden ditemukan 46,7\% (14 orang) dan penelitian Hardiani (2017) dari 30 responden ditemukan 58,2\% (18 orang) Serta dari penelitian Amalia (2016) terdapat 54,17\% (13 orang) dengan pengeluaran ASI tidak lancar.

Studi pendahuluan yang dilakukan di Puskesmas Bagu pada tanggal 11-18 Januari 2019, dari delapan ibu yang melahirkan di Puskesmas Bagu, empat diantaranya (50\%) pengeluaran ASI belum lancar/belum keluar sama sekali pada hari pertama persalinan, hal ini disebabkan oleh berbagai hal di antaranya ibu tidak pernah melakukan perawatan payudara selama hamil, rasa stress dan kelelahan setelah proses persalinan.

Pengeluaran ASI merupakan suatu interaksi yang sangat kompleks antara rangsangan mekanik, saraf dan bermacam-macam hormon. Kemampuan ibu dalam menyusui/laktasi berbedabeda. Sebagian mempunyai kemampuan yang lebih besar dibandingkan dengan yang lain. Laktasi mempunyai dua aspek yaitu pembentukan ASI (Refleks Prolaktin) dan pengeluaran ASI ( Refleks let Down/Pelepasan ASI) ${ }^{16}$.

Berdasarkan penelitian yang dilakukan oleh Nur Safitri (2015) tentang Pijat Punggung dan Percepatan Pengeluaran ASI Pada Ibu Post Partum didapatkan hasil 70\% ibu ASI keluar menetes dan $30 \%$ ibu ASI keluar memancar pada ibu yang diberi perlakuan pijat punggung, sedangkan yang tidak diberi perlakuan pijat punggung seluruh responden $(100 \%)$ ASI keluar menetes, dengan kata lain pijat punggung dapat mempercepat pengeluaran ASI.

Hasil penelitian yang dilakukan Fitrah Nurhanifah (2013) bahwa terdapat perbedaan yang signifikan antara intervensi massage punggung dengan kompres hangat payudara, dimana pada 
kelompok intervensi massage punggung didapatkan nilai p-value lebih kecil dari nilai p-value intervensi kompres hangat payudara $(0.000<0.002)$, sehingga dapat disimpulkan bahwa pemberian intervensi massage punggung lebih efektif melancarkan produksi ASI daripada kompres hangat payudara. Sedangkan penelitian yang dilakukan Baiq Eka Putri saudia (2016) menemukan adanya pengaruh yang signifikan endorphin massage terhadap peningkatan produksi ASI dimana endorphin massage bisa dijadikan sebagai terapi alternative yang efektif dalam meningkatkan poduksi ASI serta pelaksanaan postpartum blues.

Masase endorphin atau pijat endorphin merupakan suatu teknik sentuhan dan pemijatan ringan di sekitar leher, punggung dan lengan. Dikembangkan pertama kali oleh Constance Palinsky yang digunakan untuk mengelola rasa sakit. masase ini biasanya dilakukan pada ibu bersalin, riset membuktikan bahawa teknik ini meningkatkan pelepasan hormon endorphin (memberikan rasa nyaman dan tenang) dan hormon oksitosin, sehingga bila ibu post partum diberikan masase endorphin maka akan memberikan rasa nyaman dan tenang selama masa laktasi sehingga meningkatkan respon hipofisis posterior untuk memproduksi hormon oksitosin yang dapat meningkatkan let down reflex. Oleh karena itu tujuan dari penelitian ini adalah untuk mengetahui pengaruh masase endorphin terhadap peningkatan produksi asi pada ibu post partum di wilayah kerja Puskesmas Bagu.

\section{METODE}

Jenis penelitian ini adalah penelitian eksperimen semu (quasi experiment) dengan desain penelitian non equivalen control group design ${ }^{29}$. Metode eksperimen merupakan salah satu metode kuantitatif, digunakan terutama apabila peneliti ingin melakukan percobaan untuk mencari pengaruh variabel independen/perlakuan tertentu terhadap variabel dependen/output dalam kondisi yang terkendalikan ${ }^{29}$. Pada penelitian ini ada dua kelompok yaitu kelompok yang diberikan perlakuan dan kelompok kontrol (tidak diberikan perlakuan). Perlakuan yang dimaksud adalah masase endorphin. Pre test dan Post test dilakukan dengan mengobservasi produksi ASI ibu yaitu melihat faktor bayi antara lain BAB, BAK, karakteristik BAB dan BAK, lama tidur bayi dan berat badan bayi sebelum dan sesudah mendapat perlakuan.

Sampel penetitian adalah 30 ibu post partum dengan pengeluaran ASI tidak lancar yang terbagi menjadi dua kelompok yaitu 15 ibu pada kelompok yang diberikan perlakuan masase endorphin dan 15 ibu pada kelompok kontrol. Sampel ditentukan dengan metode non probability sampling menggunakan accidental sampling yang daimbil berdasarkan kriteria inklusi.

Variabel dalam penelitian ini adalah masase endorphin sebagai variabel independen dan peningkatan produksi ASI sebagai varibel indipenden yang dinilai berdasarkan 6 kriteria yaitu frekuensi BAB dan BAK bayi, warna urin dan feses, lama tidur setelah menyusu, penurunan berat badan bayi tidak $>10 \%$.

Ibu post partum hari ke 3 yang masuk ktiteria inklusi, 15 ibu pada kelompok perlakuan diberikan masase endorphin selama 3 hari dari hari ke 3 sampai hari ke 5 nifas sedangkan 15 ibu pada kelompok kontrol tidak diberikan masase endorphin. Penilaian produksi ASI dilakukan dengan menggunakan lembar observasi sebelum dan setelah diberikan masase endorphin.

Untuk mengetahui apakah data berdistribusi normal atau tidak menggunakan uji normalitas yaitu uji Shapiro Wilk, jika data tidak berdistribusi normal maka untuk menganalisis pengaruh masase endorphin terhadap peningkatan produksi ASI pada ibu post partum menggunakan uji Wilcoxon Signed Rank Test yang diolah dengan SPPS for Windows version 20. 


\section{HASIL DAN PEMBAHASAN}

\section{KARAKTERISTIK RESPONDEN}

Penelitian ini melibatkan 30 ibu post partum dengan ASI tidak lancar. Adapun karakteristik responden seperti pada tabel berikut ini:

Tabel 1. Karakteristik responden Berdasarkan Distribusi Frekuensi Kategori Umur, Pendidikan, Pekerjaan dan Paritas Periode Maret - April $2019(\mathbf{n}=30)$

\begin{tabular}{lccc}
\hline \multirow{2}{*}{ Deskripsi } & \multicolumn{3}{c}{ Postpartum } \\
\cline { 2 - 4 } & $\begin{array}{c}\text { Perlakuan } \\
(\mathrm{n}=15)\end{array}$ & $\begin{array}{c}\text { Kontrol } \\
(\mathrm{n}=15)\end{array}$ & $\%$ \\
\hline Umur & & & \\
$\leq 20$ & 3 & 0 & 10 \\
$21-35$ & 11 & 15 & 87 \\
$>35$ & 1 & 0 & 3 \\
\hline Pendidikan & & 5 & 33,3 \\
SD & 5 & 4 & 30 \\
SMP & 5 & 3 & 16,7 \\
SMA & 2 & 3 & 20 \\
S1 & 3 & 13 & 83,3 \\
\hline Pekerjaan & 12 & 2 & 10 \\
IRT & 1 & 0 & 6,7 \\
Guru & 2 & 7 & 40 \\
Pedagang & & 8 & 60 \\
\hline Paritas & 5 & & \\
Primipara & 10 & & \\
Multipara & & &
\end{tabular}

Berdasarkan tabel di atas didapatkan karakteristik ibu post partum lebih banyak pada kelompok umur 21 - 35 tahun yang merupakan masa subur wanita yaitu sebesar $87 \%$ (26 orang) dan sebagian besar memiliki pendidikan SD itu sebesar 33,3\% (10 orang) dan SMP sebesar 30\% (9 orang). Deskripsi data pasien juga terlihat bahwa dari $30 \mathrm{ibu}$ post partum rata-rata bekerja sebagai ibu rumah tangga (IRT) yaitu sebesar 83,3\% (25 orang). Sedangkan berdasarkan distribusi paritas lebih banyak memiliki paritas Multipara yaitu sebesar $60 \%$ (18 orang).

Menurut Irianto (2014), usia sangat berpengaruh terhadap proses reproduksi dimana usia yang dianggap optimal untuk kehamilan dan melahirkan adalah antara 20-35 tahun, berbahaya pada usia 16 tahun ke bawah dan 35 tahun ke atas sedangkan menurut paritas, kehamilan yang paling optimal adalah kehamilan kedua dan keempat serta berisiko untuk kehamilan pertama dan kehamilan setelah kehamilan keempat. Menurut irianto (2014) juga menyatakan bahwa usia dan paritas tidak berhubungan atau kecil hubungannya dengan produksi ASI.

Ibu yang tidak bekerja (ibu rumah tangga) bisa mengoptimalkan waktu untuk merawat bayi dan bisa tetap menyusui bayinya seperti biasa, karena isapan bayi saja sudah cukup untuk menjaga suplai ASI, sedangkan pada ibu yang harus meninggalkan bayi untuk bekerja menurut Irianto (2014) ibu dapat memerah ASI dan ditampung dalam gelas dan diberikan pada bayi dengan menggunakan sendok secara perlahan agar reflex menghisap bayi tidak tidak terpengaruh dan tidak berubah saat ibu pulang dan menyusui bayinya kembali, sedangkan menurut Asti Praborini, dkk (2018) apabila ibu bekerja dan dan terpisah dengan bayi, ibu perlu memerah ASI stiap 3 sampai 4 jam utnuk menjaga produksi ASI dan apabila ibu sudah pulang kerja ibu perlu menyusui bayinya langsung dari payudara, terutama saat tidur pada malam hari, sehingga isapan bayi saat malam penting untuk menjaga kelanjutan produksi ASI. 
Di wilayah penelitian, usia ibu yang bersalin didominasi umur 20-35 tahun dengan paritas lebih dari 1 kali, hal ini dikarenakan sebagian besar di wilayah penelitian remaja menikah di usia dini. Sehingga rata-rata pendidikan terakhir ibu di dominasi oleh lulusan SD dan SMP. Hal ini juga berpengaruh terhadap pekerjaan ibu dimana sebagian besar menjadi ibu rumah tangga.

\section{PRODUKSI ASI SEBELUM DIBERIKAN MASASE ENDORPHIN}

Produksi ASI ibu post partum sebelum diberikan perlakuan masase endorphin digambarkan dalam tabel di bawah ini:

Tabel 2. Produksi ASI Sebelum diberikan Massase Endorphin

\begin{tabular}{lll}
\hline \multicolumn{2}{c}{ Kelompok } & Rerata \pm stan.dev \\
\hline Kontrol & Pre & $2.667 \pm 1.10122$ \\
\hline Perlakuan & Pre & $2.400 \pm 0.89686$ \\
\hline
\end{tabular}

Produksi ASI sebelum diberikan masase endorphin pada kelompok perlakuan dengan rerata 2.400 dan kelompok kontrol dengan rerata 2.667, hal ini menunjukkan bahwa produksi ASI pada semua sampel ibu post partum termasuk tidak lancar berdasarkan indikator penilaian produksi ASI.

Pembentukan ASI (Refleks Prolaktin) dimulai sejak kehamilan. Selama kehamilan terjadi perubahan-perubahan payudara terutama besarnya payudara, yang disebabkan oleh adanya proliferasi sel-sel duktus laktiferus dan sel-sel kelenjar pembentukan ASI serta lancarnya peredaran darah pada payudara, namun pengeluaran air susu dihambat oleh hormon estrogen (Maryunani, 2009). Pada hari kedua atau ketiga pasca persalinan, kadar estrogen dan progesteron turun drastis, sehingga pengaruh prolaktin lebih dominan dan pada saat inilah mulai terjadi sekresi ASI ${ }^{23}$.

Menurut Ummah (2014), penurunan produksi ASI dan pengeluaran ASI pada hari-hari pertama setelah melahirkan dapat disebabkan kurangnya rangsangan hormon prolaktin dan oksitosin yang berperan dalam dalam kelancaran produksi dan pengeluaran ASI. Tidak keluarnya ASI tidak semata karena produksi ASI tidak ada atau tidak mencukupi karena dihambat akibat hambatan sekresi oksitosin. Hormon oksitosin disebut juga dengan hormon cinta kasih, sehingga bila kondisi ibu senang, tenang dan nyaman, produksi oksitosin akan meningkat (Roesli, 2009), oleh karena itu masase endorphin yang bisa merangsang sekresi hormon okstosin diharapkan bisa meningkatkan produksi dan pengeluaran ASI.

Di wilayah penelitian dari seluruh sampel diperoleh produksi ASI yang tidak lancar, hal ini merupakan hal yang normal pada tiga hari pertama pasca persalinan tetapi apabila dibiarkan dapat menurunkan produksi ASI yang mengakibatkan bayi kekurangan ASI dan sebagian besar bayi pada akhirnya akan diberikan susu formula untuk memenuhi kebutuhan nutrisi bayi. tidak lancarnya ASI pada ibu post partum disebabkan karena di wilayah kerja Puskesmas Bagu, ibu hamil trimester III tidak pernah melakukan perawatan payudara sehingga ketika melahirkan ASI menjadi tidak lancar, dan juga kelelahan setelah melalui proses persalinan dan juga kurangnya pengetahuan ibu tentang nutrisi yang dibutuhkan ibu selama hamil, nifas dan menyusui serta mitos-mitos yang masih ada di masyarakat tentang pantangan makanan yang boleh dikonsumsi maupun tidak boleh sehingga berpengaruh pada pengeluaran ASI ibu.

\section{PRODUKSI ASI SETELAH MASASE ENDORPHIN} berikut:

Produksi ASI setelah diberikan masase endorphin dideskripsikan dalam tabel sebagai 
Tabel 3. Produksi ASI setelah diberikan Masase Endorphin

\begin{tabular}{lcc}
\hline \multicolumn{2}{c}{ Kelompok } & Rerata \pm stan.dev \\
\hline Kontrol & Post & $3.267 \pm 0.67223$ \\
\hline Perlakuan & Post & $4.933 \pm 0.55635$ \\
\hline
\end{tabular}

Produksi ASI setelah diberikan masase endorphin pada kelompok kontrol adalah dengan rerata 3.267 dan pada kelompok perlakuan dengan rerata 4.933, hasil penelitian ini menunjukkan bahwa terdapat perbedaan yang bermakna rerata produksi ASI kelompok perlakuan atau ibu post partum yang diberikan masase endorphin baik pre maupun post dengan $(p$-value $=0.001<\propto$ ), dimana $\propto=0.05$. Bila berdasarkan nilai reratanya terlihat ada peningkatan rerata produksi ASI yang signifikan pada kelompok perlakuan sebelum dengan setelah diberikan masase endorphin. Sedangkan pada kelompok kontrol tidak ada perbedaan yang bermakna produksi ASI pada kelompok kontrol atau pada ibu post partum yang tidak dilakukan tindakan masase endorphin baik pre maupun post dengan nilai rerata $p$-value $=0.259>\propto$ ).

Faktor-faktor yang mempengaruhi produksi ASI adalah dari faktor ibu dan bayi, dimana faktor ibu dari segi fisik yaitu, status kesehatan, nutrisi, umur dan paritas, bentuk puting, ketidaknyamanan akibat nyeri, dan dari segi psikologi ibu yaitu kecemasan atau perasaan tertekan (stress) saat menyusui dapat menghambat jumlah ASI yang keluar, motivasi atau keinginan yang kuat dari ibu untuk menyusui bayinya meskipun terkadang menemui kendala saat menyusui juga berpengaruh terhadap kelancaran pengeluaran $\mathrm{ASI}^{28,30}$.

Banyak hal yang bisa dilakukan ibu untuk memperbanyak ASI yaitu dengan meningkatkan frekuensi menyusui, ibu harus dalam keaadan relaks atau menghindari stress dalam hal ini ada dukungan psikologis dari suami, keluarga dan juga bidan, menyusui sedini mungkin segera setelah melahirkan dan mengkonsumsi makanan yang begizi dengan nutrisi lengkap, cukup kalori dan cukup air ${ }^{12}$.

Hasil penelitian ini sesuai dengan penelitian Sari Dewi (2017), yang menunjukkan bahwa terdapat perbedaan kelancaran produksi ASI antar kelompok pijat punggung dan kelompok kontrol yaitu ibu yang mendapatkan intervensi kombinasi pijat punggung dan endorphin berpeluang

mengalami kelancaran produksi ASI 0,2 kali lebih banyak dibandingkan dengan subjek yang tidak mendapatkan perlakuan, sedangkan menurut Siti Erniyati (2014), volume ASI ibu post partum yang diberikan intervensi pijat woolwich dengan endorphin lebih besar dibandingkan dengan ibu postpartum pada kelompok kontrol. Perbedaan produksi ASI ibu post partum yang diberikan intervensi masase endorphin dengan kelompok kontrol juga ditemukan, menurut Saudia Putri (2016) ada peningkatan rerata produksi ASI yang signifikan pada kelompok perlakuan sebelum dan setelah diberikan masase endorphin dibandingkan dengan kelompok kontrol.

Ibu post partum yang telah diberikan masase endorphin terbukti dapat meningkatkan produksi ASI dibandingkan dengan yang tidak diberikan produksi ASI hal ini dikarenakan selama diberikan masase endorphin ibu juga diberikan motivasi untuk menyusui bayinya sehingga merasa lebih nyaman dan merasa lebih percaya diri untuk menyusui bayinya sehingga memperlancar pengeluaran ASI pada ibu.

\section{PENGARUH MASASE ENDORPHIN TERHADAP PRODUKSI ASI}

Setelah dilakukan hasil uji normalitas data menggunakan uji Shapiro-Wilk diperoleh nilai signifikansi untuk semua data kelompok produksi ASI kurang dari 0,05 artinya data tersebut tidak tersebar normal. Sehingga untuk melakukan uji beda antara data pre dan data post menggunakan statistika non-parametrik, yaitu uji bertanda peringkat wilcoxon (uji data 2 sampel berhubungan) dan dijelaskan secara rinci terlihat pada tabel di bawah ini. 
Tabel 4. Hasil uji Pengaruh Masase Endorphin terhadap Produksi ASI pada kelompok perlakuan dan kelompok kontrol di Wilayah Kerja Puskesmas Bagu $(n=15)$

\begin{tabular}{rrrr}
\hline \multicolumn{2}{c}{ Kelompok } & Rerata \pm stan.dev & p-value \\
\hline Kontrol & Pre & $2.667 \pm 1.10122$ & \multirow{2}{*}{0.259} \\
\hline Post & $3.267 \pm 0.67223$ & \\
\hline Perlakuan & Pre & $2.400 \pm 0.89686$ & 0.001 \\
\hline Post & $4.933 \pm 0.55635$ & \\
\hline
\end{tabular}

Hasil penelitian menunjukkan bahwa terdapat perbedaan yang bermakna rerata produksi ASI kelompok perlakuan atau ibu post partum yang diberikan masase endorphin baik pre maupun post dengan $(p$-value $=0.001<\propto)$, dimana $\propto=0.05$. Jika berdasarkan nilai reratanya terlihat ada peningkatan rerata produksi ASI yang signifikan pada kelompok perlakuan sebelum dengan setelah diberikan masase endorphin. Hal ini berarti bahwa produksi ASI pada kelompok ibu dengan post partum yang diberikan masase endorphin terlihat menunjukkan ada peningkatan rerata produksi ASI bila dibandingkan dengan ibu post partum yang tidak diberikan masase endorphin. Sehingga dapat disimpulkan bahwa perlakuan dengan masase endorphin memiliki pengaruh yang signifikan terhadap peningkatan produksi ASI ibu post partum.

Produksi ASI dapat ditingkatkan dengan tehnik masase Endorphin yaitu suatu teknik sentuhan dan pemijatan ringan pada leher, lengan dan tangan. Nurhanifah (2013), Menyatakan bahwa pemberian masase pada punggung lebih efektif daripada kompres hangat payudara untuk meningkatkan produksi ASI. Kondisi ini dikarenakan saat dimasase, saraf punggung akan merangsang pengeluaran endorphin di dalam tubuh yang secara tidak langsung akan merangsang refleks oksitosin. Ketika diberikan masase punggung, saraf punggung akan mengirimkan sinyal ke otak untuk mengeluarkan oksitosin, yang akan menyebabkan kontraksi sel myoepitel yang akan mendorong keluarnya ASI, karena saraf payudara dipersarafi oleh saraf punggung (saraf dorsal) yang menyebar disepanjang tulang belakang. Lancarnya pengeluaran ASI disebabkan juga karena meningkatnya sirkulasi darah pada daerah payudara setelah diberikan massage punggung. Hal ini didukung juga oleh penelitan yang dilakukan Mas'adah (2014), menyatakan bahwa Metode "SPEOS" (Stimulasi Pijat Oksitosin, Pijat Endorphin dan Sugestif) merupakan salah satu metode efektif untuk membantu memperlancar produksi ASI pada ibu dengan sectio secaria.

Menurut Dalimartha (2009) teknik pemijatan pada titik tertentu dapat menghilangkan sumbatan dalam darah sehingga aliran darah dan energi di dalam tubuh akan kembali lancar. Sisk et al (2010), menyatakan bahwa massage mempunyai manfaat baik secara fisiologis maupun psikologis. Manfaat massage meliputi mencipta kan respon relaksasi, meningkatkan proses metabolisme, meningkatkan fungsi jaringan limfatik, mempercepat penyembuhan dan relaksasi otot, mengurangi ketegangan otot dan tingkat stres. Mulyati (2009) menyatakan bahwa efek massage juga dapat meningkatkan kadar serotonin dan dopamine sehingga memicu penurunan ketidaknyamanan, kelelahan, stres dan depresi. Kondisi ini sama yang dirasakan post massage punggung, responden merasa rileks dan nyaman. Pengurangan ketidaknyamanan, kelelahan, stres dan depresi pada ibu menyusui akan membantu lancarnya pengeluaran ASI.

\section{KESIMPULAN}

Karakteristik ibu post partum menurut kelompok umur sebagian besar responden adalah $21-35$ tahun (87\%), berpendidikan SD dan SMP sebanyak 19 orang (63.3\%), bekerja sebagai ibu rumah tangga sebanyak 25 orang (83.3\%), dan multipara sebanyak 18 orang $(60 \%)$. Produksi ASI sebelum diberikan masase endorphin pada kelompok perlakuan adalah dengan rerata 2.400 sedangkan pada kelompok kontrol dengan rerata 2.667. Peningkatan produksi ASI setelah diberikan masase endorphin adalah mengalami peningkatan yaitu pada kelompok perlakuan 
adalah dengan rerata 4.933 dan pada kelompok kontrol adalah dengan rerata 3.267 dan terdapat pengaruh masase endorphin terhadap peningkatan produksi ASI pada ibu post partum dengan $p$ $=0.001(p<\propto)$

\section{SARAN}

Produksi ASI berhubungan dengan kesuksesan ASI Eksklusif, diharapkan bidan menguasai tehnik masase endorphin dan bisa diterapkan dalam pelayanan serta dapat diterapkan kepada masyarakat khususnya Ibu post partum dengan ASI tidak lancar sehingga bisa memperlancar ASI.

\section{DAFTAR PUSTAKA}

1. Amalia, Rizki (2016). Hubungan Stress dengan Kelancaran ASI pada Ibu Menyusui Pasca Persalinan di RSI A. Yani Surabaya. Jurnal Ilmiah Kesehatan, Vol. 9, No. 1, hal 12-16.

2. Aprilia, Y. (2011). Gentle Birth, Melahirkan Nyaman Tanpa Rasa Sakit. Jakarta: PT.Gramedia Widia saran Indonesia.

3. Ariani (2009). Ibu Sususi Aku. Bandung: Khazanah Intelektual.

4. Berkah Pamuji, S. E. (2014). Pengaruh Kombinasi Metode Pijat Woolwich dan Endorphin Terhadap Kadar Hormon Prolaktin dan Volume ASI. Jurnal Ilmu dan Teknologi Kesehatan. ISSN: 2088-4435.

5. Dalimartha, S. (2009). Care Yourself, Hipertensi. Jakarta: Penebar Plus.

6. Delima, Mera (2016). Pengaruh Pijat Oksitosin Terhadap Peningkatan Produksi ASI Ibu Menyusui di Puskesmas Plus Mandiangin. Jurnal IPTEKS Terapan, Vol. 9, No 282-293, ISSN: 1979-9292.

7. Eka Putri Saudia, B \& Arini Murni, N. (2016). Pengaruh Endorphin Massage Terhadap Peningkatan produksi ASI Pada Ibu yang Terdeteksi Post Partum Blues dengan Skrinning EPDS (Edinburgh ost Partum Depression Scale) di Puskesmas Wilayah Kerja Sekota Mataram. Jurnal kesehatan Prima Vol.11 No. 1, ISSN: 2460-8661.

8. Hardiani, Ratna Sari (2017). Status Paritas dan Pekerjaan Ibu Terhadap Pengeluaran ASI pada Ibu Menyusui 0-6 bulan. NurseLine Journal Vol. 2 No. 1, ISSN: 2540-7937.

9. Hastuti, Puji, \& Wijayanti, Irfana Tri (2017). Analisis Deskriptif yang Mempengaruhi Pengeluaran ASI pada Ibu Nifas di Desa Sumber Kecamatan Sumber Kabupaten Rembang. The $6^{\text {th }}$ Univesity Research Colloquium 2017, ISSN: 2407-9189.

10. Irianto, Koes (2014). Biologi reproduksi. Bandung: Alfabeta.

11. Manuaba, I.B.G. (2010). Ilmu Kebidanan, Penyakit Kandungan, dan Keluarga Berencana untuk Pendidik Bidan. Jakarta: Penerbit buku kedokteran. ECG.

12. Marmi (2011). Asuhan Kebidanan pada Masa Nifas "Peuperium Care”. Yogyakarta: Pustaka Pelajar.

13. Maryunani, Anik (2012). Inisiasi Menyusui Dini, ASI Eksklusif dan Manajemen Laktasi. Jakarta: Trans Info Media.

14. Mas'adah, Rusmini (2010). Teknik Meningkatkan dan Memperlancar Produksi ASI Pada Ibu Post Seksio Caesarea. Jurnal Kesehatan Prima, Volume: 9, No. 2, ISSN 1978-1334.

15. Mochtar, R. (2011). Sinopsis Obstetri. Obstetri Fisiologi Dan Obstetri Patologi. Jilid 1. Jakarta: Penerbit buku kedokteran EGC.

16. Mulyati, Leli (2009). Pengaruh Masase Kaki Secara Manual Terhadap Sensasi Proteksi, Nyeri dan Ankle Brachial Index (ABI) Pada Pasien Diabetes Mellitus Tipe 2 Di Rumah Sakit Umum Daerah Curup Bengkulu. Universitas Indonesia Library.

17. Nirwana, A.B. (2011). Psikologi Kesehatan Wanita (Remaja, Menstruasi, Menikah, Hamil, Nifas, Menyusui. Yogyakarta: nuMed.

18. Nurhanifah, F. (2013). Perbedaan Efektivitas Massage Punggung dan Kompres Hangat terhadap Peningkatan Kelancaran Produksi ASI Di Desa Majang Tengah Wilayah Kerja Puskesmas Pamotan Dampit Malang. Jurnal Keperawatan, ISSN 2086-3071. 
19. Nur Safitri, W. dkk. (2014). Pijat Punggung dan Percepatan ASI Pada Ibu Post Partum. Jurnal Informasi Kesehatan (JIKI), Volume 1, No 2, ISSN 2460-0334.

20. Praborini A, Ayu Wulandari R. (2018). Anti Stress Menyusui. Jakarta: Kawan Pustaka.

21.Prasetyono, Dwi Sunar. (2009). Buku Pintar ASI Eksklusif. Yogyakarta : Diva Press

22. Purwanti E. (2012). Asuhan Kebidanan Untuk Ibu Nifas. Yogyakarta: Cakrawala Ilmu.

23. Purwoastuti, E \& Elizabeth, S. W. (2017). Asuhan Kebidanan Masa Nifas \& Menyusui. Yogyakarta: Pustaka Baru Press.

24. RISKESDAS (2018). Laporan Hasil Riset Kesehatan Dasar (Riskesdas). Jakarta: Kementrian Kesehatan RI.

25. Sari Dewi, A. dkk, (2017). Kombinasi Pijat Punggung dan Endorphin Terhadap produksi ASI Pada Ibu Post Partum. Jurnal Ilmiah Kesehatan Keperawatan, Volume 13.

26. SDKI. (2012). Survei Demografi dan Kesehatan Indonesia. Jakarta.

27. Sisk, P, Quandt, S, Parson, N, \& Tucker, J. 2010, Breast milk expression and maintenance in mothers of very low birth weight infants: supports and barriers, Journal of Human Lactation, Vol. 26, Issue 4, pp. 368-375.

28. Soetjiningsih (2017). Tumbuh Kembang Anak. Cetakan Ke-2. Jakarta: EGC.

29. Sugiyono (2018). Metode Penelitian Kuantitatif. Bandung: Alfabeta.

30. Suradi R, Tobing HKR. (2011). Manajemen Laktasi. Cetakan Ke-5. Jakarta: Program Manajemen Laktasi Perkumpulan Perinatologi Indonesia

31. Ummah, Faizatul (2014). Pijat Oksitosin untuk Mempercepat Pengeluaran ASI pada Ibu Pasca Salin Normal di Dusun Sono Desa Ketanen Kecamatan Panceng Gresik. Jurnal Surya Vol. 02, No. XVIII. 